Technological University Dublin

ARROW@TU Dublin

1998-01-01

\title{
The Changing Nature of Theory and Practice in Marketing: on the Value of Synchrony
}

Aidan O'Driscoll

Technological University Dublin, Aidan.odriscoll@tudublin.ie

John Murray

Trinity College Dublin

Follow this and additional works at: https://arrow.tudublin.ie/buschmarart

Part of the Business Commons

\section{Recommended Citation}

O'Driscoll, A., Murray, J.: The Changing Nature of Theory and Practice in Marketing: on the Value of Synchrony. Journal of Marketing Management, 1998, vol. 14, no. 5, pp. 451-464.

This Article is brought to you for free and open access by the School of Marketing at ARROW@TU Dublin. It has been accepted for inclusion in Articles by an authorized administrator of ARROW@TU Dublin. For more information, please contact arrow.admin@tudublin.ie, aisling.coyne@tudublin.ie,gerard.connolly@tudublin.ie.

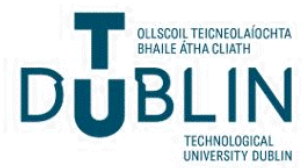




\section{Aidan \\ O'Driscoll and Practice in Marketing: On the Value of John A. Murray Synchrony}

Any academic discipline with a closely associated area of professional endeavour is profoundly affected by the relationship between its theory and practice. Synchrony in theory and practice adds value to the management of enterprise and to the advance of the discipline. Mindful of this assertion, this article explores the changing nature of theory and practice in marketing. It examines current trends in marketing practice which are Dublin Institute of occurring as a result of change in markets, technology Technology

Trinity College Dublin and organisations. It assesses the state of theory in six subfields of marketing. It also considers developments in closely related management disciplines as well as in a number of cognate fields. The authors suggest there is considerable asynchrony at the moment and that this is, in general, bad for both theorist and practitioner: doldrums in the marketing academy and the threatened end of the marketing department in business. To restore greater synchrony with practice, it is argued that marketing theory needs not just to deal with the new realities of marketing but also to develop its theories of markets, managing and organisation.

\section{Introduction}

Any academic discipline with a closely associated area of professional endeavour is profoundly affected by the relationship between its theory and practice. In the history of most professions practice has run ahead of theory. This happens because practice is immediate: problems must be solved, issues dealt with, challenges confronted. As a result, practice evolves of necessity. Architects had to produce structures without an adequate theory of materials; engineers crafted mechanisms without fully understanding their dynamics; doctors did their utmost to save lives without a complete understanding of physiology; and managers built and directed state, military and commercial organisations without a complete understanding of their properties and processes.

Theory develops differently. It advances because inquiring minds are drawn to understand, explain, predict. They are drawn because the discipline is intrinsically interesting to them; because the problems confronted are of great importance to their society; because they are rewarded for their inquiry. It is no surprise that medicine, engineering and architecture have seen theory blossom, and in the case of medicine and engineering, witnessed theory moving 
from a position of playing 'catch-up' to a position of leadership. But in the case of management, it is only in the recent historical past that the scale and pervasiveness of organisations and their pivotal role in individual and collective life has become a common reality.

Because of this, the relationship between theory and practice is less well developed than it might be in other disciplines, and theory itself is still often rudimentary. Micklethwaite and Wooldridge's (1996) book makes the point rather scathingly with its title The Witch Doctors: What the Management Gurus are Saying, Why it Matters and How to Make Sense of it. The analogy is clear if not flattering to management theorists - management as a discipline does not provide much more by way of theory than witch doctors had at their disposal in their village practice. They ask "why does a discipline that contains so much sense contain so much nonsense as well?" and respond "one answer is that management theory is still such a young discipline, in which canonical texts and defining methodologies are still being developed... management theory feels like as if it is around 100 years younger than disciplines such as economics". Their critique of management theory has four grounds which link to a description of the discipline as adolescent:

"that it is constitutionally incapable of self-criticism; that its terminology usually confuses rather than educates; that it rarely rises above basic common sense; and that it is faddish and bedevilled by contradictions that would not be allowed in more rigorous disciplines" (Micklethwaite and Wooldridge, 1996, 369, 15).

For an adolescent discipline the relationship between theory and practice must be especially important. On the one hand there is the surfeit of energy, enthusiasm, and determination; on the other the accompanying incoherence, indiscipline and fashion swings. Yet in the world of practice, rapid technological and societal evolution demands that managers build learning organisations the work of mature rather than adolescent minds and concepts. As the limitations of traditional organisational hierarchy are brought into ever sharper Pocus, companies are designed and managed in a way that emphasise horizontal processes and flatter structures. This is being achieved in the manner in which the early engineers of the industrial revolution - with a mixture of trial and error and evolving theory - brought their startling new machines to bear on society's production processes. The new organisational forms bring with them radical implications. Learning becomes the axial principle of organisations and replaces control as a fundamental job of management (Senge, 1990). Learning has its own dynamic. It involves engagement with theory and practice. The manager looks to relevant concepts, models and theories to interpret situations, guide decision making and to inform practice. Just as practice, seen as a series of experiments, leads to generalisation and theory building through careful observation. We advance deductively and inductively - theory fuelling practice, practice fuelling theory. The academician studies practice and the laboratory of the real world to abstract and refine theory; the manager studies theory to make sense of reality 
and to inform action.

The changing nature of theory and practice and their interface inevitably takes on a pattern that indicates greater or lesser levels of harmony and contemporaneity in development. In some instances, the growth of theory and practice will be concordant and simultaneous, while in others, it will be disjointed and time-lagged. In the latter case, it is possible to argue that learning involves a higher cost. The gap between theory and practice carries opportunity costs and learning curve expenses to the parties involved. Stated positively, synchrony in theory and practice adds value to the management of enterprise and to the advance of the discipline, and in the case of a management discipline like marketing, to the ultimate relevance of the thinking that takes place in the academy.

Mindful of this assertion, this paper explores the changing nature of theory and practice in marketing and their interface. It examines current trends in marketing practice which are occurring as a result of change in markets, technology and organisations. It assesses the state of theory in six subfields of marketing: consumer behaviour, marketing communications, relationship marketing, business to business marketing, services marketing, and green marketing. These are choosen not out of any sense of inclusiveness but rather as a reflection of the authors' perceptions of subfields that are or should be of significance. It considers some of the developments in closely related management disciplines as well as some cognate fields. Once again, the survey reflects the authors' concerns and interests and does not claim any greater survey or encyclopaedic rationale. Finally, the paper considers the nature and quality of synchrony in the current development of marketing theory and practice. We suggest that there is considerable asynchrony at the moment and that this is, in general, bad for both theorist and practitioner: doldrums in the marketing academy and the threatened end of the marketing department in business. Exhibit 1 illustrates the structure of the discourse.

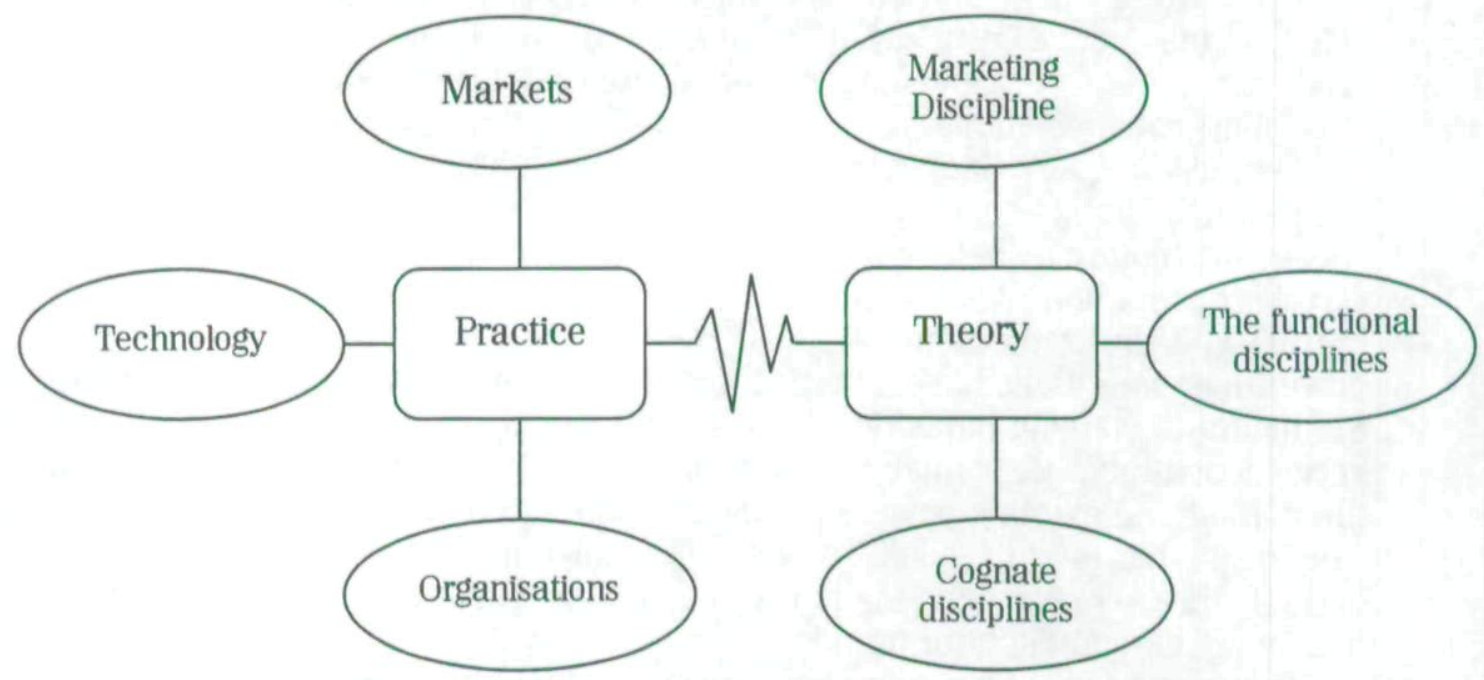

Exhibitl. The Changing Nature of Theory and Practice in Marketing 


\section{Change in the Marketplace}

\section{Markets}

Following the Second World War, industrial output in Western economies grew at an unprecedented level until slowed by the oil crises of the seventies. Most markets exhibited high growth, stable behaviour and stable structures. By contrast, as the millennium approaches, Western markets show more modest levels of growth, and many have experienced recent recession, while Asian markets experience explosive growth. However, the services sector has grown consistently and much more substantially than the manufacturing sector whose growth had been central to the development of the large industrial enterprise and the multinational firm. Western governments have adopted more market based, laissez-laire economic polices which have involved considerable deregulation. And while increasing Pragmentation is observable in many markets as the popularity of vertical integration recedes, this appears to be accompanied by more complex networks and interdependencies in the resulting market structures. Globalisation of competition has become an underlying feature of markets. The growth of Japan, the Pacific Rim countries and China results in international trade being concentrated in a triad of the US, Europe and Asia. This demands that rapidly internationalising firms, particularly Western ones, apprehend new cultures and ways of transacting business. Real time communications and ever cheaper transport reduce personal and physical distance, but overcoming the residual 'psychic' distance yields competitive superiority.

The era of trusting, easily defined, homogeneous consumers has also faded in so far as it ever existed in a world where suppliers held power. The customer to whom the marketer now appeals is sophisticated, sceptical, literate, demanding - harder to persuade and harder to retain. This is particularly true of younger consumers for whom consumption is an act of self-expression and empowerment as well as an act of economic necessity. The propensity of marketers to segment into smaller 'micro' categories, and to build databases, allied to the increasing array of means of communication, both reflects and produces audience fragmentation and decreased effectiveness of traditional mass marketing techniques.

Channels of distribution are changing significantly. An important feature of the past decade has been the increasing levels of performance in terms of cost, speed and control, abetted by new technology, of channels of product and service distribution. Just-in-time delivery modes, automated teller machines (ATMs) and electronic point-of-sale (EPOS) systems are all in wide use. New powerful organisations have emerged and grown along the distribution chain. In the food and clothing industries, for example, retailing structures have become very concentrated with small numbers of retailers controlling a greater share of the market and exerting power and control back through the 'upstream' sectors. One result has of this been the rise of retailer and distributor own brands (DOBs) threatening, and in many cases overwhelming, the traditional hegemony of manufacturer brands.

Firms and their managers have risen to the challenges of new market 
structures and customer characteristics in diverse ways and many have successfully adapted their competences and assets. A number have managed their marketing and strategy in a way which conventional thinking and theory did not prescribe, and changed the 'rules of the game' to their advantage. The Cott Corporation, a global company manufacturing and canning cola under own label brands for hundreds of retailers in North America, Europe and Asia, capitalised innovatively on the decade's growth in retailer power and DOBs. It provides an interesting example of a firm whose actions have had a profound effect on its industry's configuration. Its success dealt a stinging blow to the two players which had dominated the cola industry, Coca-Cola and Pepsi-Cola, characterised by one academic as a 'slaying (of') the giants' (Sparks, 1995).

\section{Technology}

The past decade has seen important new modes of manufacturing and service supported by new integrated information structures and technology take root firmly in Western firms. The provenance of total quality management (TQM), world class manufacturing (WCM), just-in-time work flows and supply chain management lies in Japanese ways of production. These approaches stress multidisciplinary integration, parallel as well as sequential tasking, speed to market, high product quality and dedicated customer service. They highlight the failure of conventional Western 'chimneystack' management with its functional 'bunkers' - including marketing - embodying an abstract notion of 'marketing orientation' concerning corporate commitment to customers and markets but a practical unwillingness to get out in the field and 'deliver' on customer service and satisfaction. In this regard the production and operations departments of firms which have implemented manufacturing and service methods such as TQM and WCM with their driven customer focus have stolen a march on (if not the clothes of!) marketing. The new approaches to operations and supply chain management have facilitated the emergence of realistic forms of mass customisation in many markets (Westbrook and Williamson, 1993).

The role of electronic point-of-sale (EPOS) systems in altering the nature of competition has been alluded to above. Technology, greater leisure time availability and changing socio-economic and demographic factors have resulted in fractionalisation in advertising media, particularly TV and print media. New magazines and newspaper titles, extra national, regional and global television channels, the development of the World Wide Web, the Internet and multimedia instruments have all conspired to make the marketer's job of communicating with the target audience more complex. This complexity is compounded by the increasing heterogeneity and segmentation in customer profiles. The need for speed-of-response in the context of shortening product life cycles and world wide real time communications is a further hurdle for the marketer.

The rise of database marketing, facilitated by the growth in computing and neural-network software technology, is a particularly striking feature of changing marketing practice. By the early nineties Kraft Foods Inc. had amassed a list of more than 30 million users of its products who had provided their names when sending in coupons or responding to some other Kraft promotion (Business 
Week, 1994). Based on the interests they expressed Kraft regularly sends them tips on such things as nutrition and exercise - as well as recipes and coupons for specific brands. Along with other leading food companies like Nestlé and Heinz Corporation, the company now complements its traditional advertising with individually targeted relational approaches using below and beyond the line techniques.

\section{Organisations}

Not surprisingly, organisations are changing profoundly in the ways in which they are structured. The possibilities and demands of new technology, real-time communication, innovative products and services and intensifying global competition have necessitated flatter structures and consequentially greater empowerment at lower levels of the organisation (Ostroff and Smith, 1992; Boehm and Phipps, 1996). Hierarchy has been overlaid with heterarchy, and a growing emphasis on process complements concern with function. The functional departmental hegemony, implicit in the organisational models of the post war years, has been reduced in favour of approaches involving crossfunctional teams stressing customer focused tasks and shared learning. High levels of vertical and horizontal integration have been replaced by modalities such as out-sourcing, partnering, strategic alliances and networks. The multinational model is evolving into a transnational structure of organisation as many large firms seek to balance the needs and advantages of international integration, local responsiveness and global learning - supported by a downsized and revamped role for corporate $\mathrm{HQ}$ (Bartlett and Ghoshal, 1989).

In the early nineties, Procter and Gamble, the original 'inventor' of the brand management system in the US of the 1930s, switched from brand to category management, i.e. all shampoos or diapers managed as a unit, and evolved multidisciplinary customer business development teams with managers from production and sales as well as marketing (George et al., 1994). The brand management model had worked spectacularly well during the era of high consumer trust, effective mass advertising, growing prosperity, homogeneous demand and poorly developed distribution channels and above all, manufacturer power. A different marketing landscape has lead to a reappraisal of existing modes of organising for brand/product management and for the effective 'delivery' of marketing company-wide. As a result, new organisational forms are evolving in the competitive struggle for survival and growth.

In summary, there has been dramatic change in the marketing firmament. Markets and firms are changing, evolving, re-shaping. The P\&G case illustrates the abandonment of a fundamental tenet of marketing organisation by its creator in its struggle for acceptable performance under new market conditions. The emergence of the Cott Corporation indicates the vulnerability of two of the world's biggest manufacturer brands in the face of an innovative reshaping of an industry's value-adding chain. The example of Kraft Foods, and others in using database marketing, charts how highly targeted, one-to-one approaches to marketing transactions and relationships are redefining the notion of market segmentation and communication. These companies provide illustrations of novel practice and of adaptation, resilience and imagination in a changing 
competitive environment. They also show that practice is often revolutionary.

\section{Change in the Academy}

\section{Change in Theory: Marketing Discipline}

How is the academy grappling with these issues of practice? It is useful to consider how the various subdisciplines of marketing are seeking to describe, explain and offer worthwhile generalisation about such phenomena. What concerns are driving research agendas in universities? What novel insights and thinking are emerging in different subfields?

We find it difficult to support any claim that the marketing discipline has been characterised in recent years by significant change in its intellectual structure and centre of gravity. We will look briefly at some of the areas that have stimulated discussion, theory building and some theory testing, but believe that overall there are few signs of paradigm shift (Kuhn, 1970). It has been argued elsewhere (Murray and O'Driscoll, 1996a; Murray, 1994 ) that the conventional wisdom of the discipline as commonly understood by both practitioner and theorist was formalised by the work of McCarthy and Kotler in the 1960s and has changed only by elaboration since then. While the discipline might be seen as displaying signs of maturity in its present set of central ideas and explanations of marketing phenomena and by a dominant process of convergence theoretically, this might also be seen as a false maturity deriving from a condition of stasis. When the juxtaposition of theory and practice is examined carefully, we suggest that the discipline in its current form is uneasily positioned in a praxis which is experiencing rapid change in the nature, structure and governance of markets themselves. Despite this, the most popular general textbooks and much of the academy's research and thinking is firmly rooted in a heyday of the sixties (O'Driscoll, 1997).

Undoubtedly the discipline is changing in some of its subfields and we will consider some of these next. It seems reasonable to start such inquiry where all marketing must ultimately begin and end - in the domain of consumer behaviour.

\section{Consumer Behaviour}

Consumer behaviour mirrors marketing itself in that its heyday of conceptual development and organisational reputation was most evident in the 1960s and 1970s. It was one of the significant sources of early development, renewal and theory building in the marketing management paradigm. It brought special stimulation, in part because it arrived in the heads of a new cohort of recruits to business schools - behavioural scientists and especially social psychologists and psychologists. With them they brought basic training in disciplines that had a much stronger commitment to theory building and testing than had been characteristic of the business school and a tool box of psycho and socio-metric methods which added significantly to the rigour and detail of research and debate. However, the area reached something of a peak in the work of those who developed the classical general models in both consumer and organisational buying behaviour (e.g., Nicosia, 1966; Howard \& Sheth,1969; 
Webster \& Wind,1972; Sheth, 1973). Since then, outstanding work continues, but a great deal of it targeted on refining the earlier pioneering research and on dealing with the early assumptions about rationality and high involvement.

Criticisms of the early models revolved about the lack of evidence for the assumed degree of rationality and for all but a relatively few purchase situations being characterised by very high customer involvement. As a result, a much wider variety of consumer and organisational decision making modes was recognised and stimulated the development of more context-bound explanations. Research focused on greater levels of customer and buyer segmentation and on identifying the characteristics and particular demands of segments such as the senior, youth and gender-based markets. The present decade has seen many in the consumer behaviour fraternity look again to the origins of consumer behaviour in order to reposition it in a wider domain within the social sciences. Consumer behaviour is seen not only as an instrument of the marketing manager but as a legitimate exploration into the nature of consumption and society (Belk, Dholakia and Venkatesh, 1996; Brown and Turley, 1997). The postmodernist perspective has been employed with playful and sometimes productive effect in the macromarketing critique (Brown, 1995, 1997).

\section{Marketing Communications}

For the consumer and manager alike, a highly visible sign of change on the marketing landscape has been the rise in novel modes of marketing communication. While advertising remains the most important communication medium for many if not most consumer goods companies, greater consumer sophistication and expectations, new and fragmenting media, the availability of highly targeted communication approaches and rising advertising costs have conspired to produce a rise in sales promotion and below the line expenditure and a greater use of instruments like direct mail and sponsorship (Meenaghan, 1995). The academy, at best, struggles to keep abreast of these developments, to chronicle best practice and to provide rudimentary typologies.

There has been little theory building concerning these occurrences other than a call for a more 'integrated' approach to managing a more complex communications mix. The detail of such prescription remains poorly articulated and while this might be excused on the grounds of the size and rapidity of change in practice (direct response marketing, loyalty scheme marketing, electronic commerce, the controversy over the effectiveness of mass advertising), it also shows signs of intellectual failure in the academy.

If such flux causes practical and reputational difficulty for model builders, it lends further weight to the concern about brands, brand loyalty and brand equity. A brand represents the desirable outcome of a seamless nexus between our understanding of consumer behaviour and marketing communication. The fortunes of the brand have been undergoing threatening change. The greater power of retailers and the growth of retailer and distributor own brands (DOBs) have caused manufacturers to reshape their branding strategies, to pocus on the administration of brand categories, and to reorganise approaches to brand management. Research and extant models such as the hierarchy of effects 
paradigm continue to seek to explain, however imprecisely, the role of advertising in nurturing brands; for "advertising may only be primus inter pares in its ability to communicate marketing messages, but it is pre-eminent in creating and sustaining brands" (Fanning, 1997). But any robust theory of marketing communication must also seek to explain the cost-effectiveness of other media in establishing long term brand loyalty. Whether it is expenditure on direct marketing or a so-called relationship programme, a trade promotion, a public affairs or a sponsorship programme, such approaches cost considerable sums of money. It must be remembered that traditional mass advertising became successful because of its ability to deliver large audiences at very low prices. Shorter term sales effects can be assessed in most cases but the strategic impact on brand equity is understood tenuously. Comprehending the 'black box' of below and beyond the line marketing communication presents academicians with a formidable challenge.

In a general sense, work in this subfield still pivots on the notion of the communication mix - an analogue of the marketing mix mental model, a focus on which has arguably limited wider marketing theory development. Issues to do with modelling and optimising a communication mix have been addressed but with limited success (Nowak and Phelps, 1996). The extension of the mix to include further and powerful elements such as electronic media, sponsorship and direct relationship linkages has added complexity to the market and managerial reality. The apparent large shifts in effectiveness as between above the line and below the line methods and expenditures, and the sustainability of manufacturer branding find few echoes in the theory building field. Selling and sales management, in so far as they are to be categorised as part of the communications subfield continue their rather Cinderella like existence, especially in European research and writing, although the developments in the area of relationship marketing offer some hope of serious theoretical attention to the area.

\section{Relationship Marketing}

The ability of the quotidian marketer and his market research company to segment a market and profile its customers is, in general, impressive. The expansion of static profiling data - census, lifestyle and financial - is coupled with a falling cost and rising power of data processing and transmission. Add to this the huge penetration of point of sale (EPOS) data capture hardware and it is now possible to expertly link customer profiling with their real-time sales value (Muranyi, 1997). This provides much of the impetus for the growth in database, direct and direct response marketing. The marketer now speaks of one-to-one marketing, of dialogue rather than monologue between seller and buyer - the days of the door to door salesperson have returned, only now she uses electronic circuitry, rather than shoe leather, to engage the customer. The possibility of establishing a direct relationship between corporate seller and individual buyer appears more tangible. However, the possibility also creates a significant challenge for both practitioners and scholars.

Relationship marketing has had a significant impact in helping to reconceptualise marketing action as relational rather than transactional. 
However much believers in the marketing management school might argue that, through the 'marketing concept', marketing has always had this relational bias, we would argue that the overwhelming emphasis in theory, as in practice, has been transactional. In this context, the emergence of interest in relationship marketing both encouraged and reflected significant changes in market practice. Its development in the late eighties reflected the need to explain and predict the observed market patterns especially in the burgeoning services sector and in the business to business field where market reality was visibly organised around series, sequences and patterns of transactions managed through time. Moreover, early research on the value of customer retention began to appear (Reicheld and Sasser, 1990) which sent a strong signal not only to the research community about the importance of relationship but also a very practical message to the practitioner community that here were some ideas with conceptual currency but also with real strategic and profit payofi. The interest in and exploration of relationships has opened a door to exciting ideas from other management disciplines (supply chain management, strategic alliances) and from cognate disciplines (trust rather than competition as the engine of markets; network theory). We have argued elsewhere that the relationship marketing subfield is an important development and one which oflers some of the starting points that could well lead to a reconceptualisation of the whole field through the development of ideas of marketing as process at both industry and firm levels and of markets as networks once again at macro and inter-firm levels of observation.

What exactly is meant by relationship marketing? Many practitioners hold a view of, and some educators teach, relationship marketing as a device or method for capturing and locking in customers, e.g. through the creation of switching costs and exit barriers based on training schemes, even afriliation clubs. This is basically a monopolising approach with little interest in two-way exchange. Relationship marketing may also be seen as an attempt to create, through regular unobtrusive communication, occasional gift giving and actual purchase, a lasting relationship between firm/seller and client through which the consumer becomes a willing partner and might speak loyally of 'my product'. This applies in a consumer, business to business and services marketing context alike. In the academy, the questions studied are what type of customer wants and needs are catered to by a relationship? What products and services are amenable to longer term relationship building? What are the building blocks of such a relationship? Notions of reciprocity, trust, power, dependency are elements of this conceptualisation - distinctly different from those of arm's length transaction, governed by contract.

Relationship marketing is also perceived as a more all-embracing reconceptualisation of marketing theory itself - a concept which encompasses the management of a diversity of relationships, networks and interaction. It reflects the shift away from the predominant Kotlerian view of marketing with its emphasis on competition, the $4 \mathrm{ps}$ and the high street consumer. It has roots in the Nordic network approach to marketing. Its study includes business systems, supply chains, virtual networks, internal marketing, internal markets and so-called non-market relationships (Gummesson, 1996a, 1996b). In many 
universities and research institutes, this relationship marketing paradigm is the focus of rigorous and some exciting thinking about the nature of markets, both consumer and industrial, and marketing.

\section{Business to Business Marketing}

When business to business marketing established itself as a separate subdiscipline in the academy, it promised to confer a number of benefits on the development of marketing theory and practice. First, it reminded us that consumer goods marketing represented only the tip of the iceberg in terms wealth-creating processes and market interactions; marketing has a key role to play in the profitable delivery of industrial products to satisfied customers. Second, it highlighted the importance of organisational buying behaviour and the particular complexity of selling to larger organisations. Third, it emphasised the role of distribution and channel management one of the most neglected of the conventional marketing mix variables.

Decades later, the promise seems poorly fulfilled. The subfield has applied existing concepts and constructs of marketing to the circumstances of industrial markets adroitly but in a situational manner rather than through a robust contingency theory. (It can be argued that such a situational approach has also been adopted by international marketing in the context of firms moving across borders, and in entrepreneurial marketing in the context of small firms.) A perusal of the most widely used, mostly North American, textbooks on business to business marketing contains little or no reference to the seminal work of the industrial marketing and purchasing group (IMP) in the late 1970s in Europe (IMP Group, 1982) or to its more recent incarnation as 'markets as networks' or the industrial network paradigm (Ford, 1990; Häkansson and Johanson, 1992). Stimulating research and model building continues to emanate about industrial markets and marketing from this European school (Easton and Häkansson, 1996).

One positive outcome of the American approach to business to business marketing has been a heightened concern for the role of sales management in marketing. Issues such as selection, motivation, incentivisation, training and sales administration are receiving increasing research attention, as are the organisational design problems attaching to category management and the reshaping of brand responsibility (Anderson, 1996).

\section{Services Marketing}

If US academe has been slow to theorise robustly about business to business marketing, the same is not true of services marketing. From the servuction service framework (Langeard et al., 1981) through to the SERVQUAL model (Parasuraman et al., 1988) and its various extensions, a literature of conceptual rigour and genuine transatlantic discourse has grown. It has responded to the growing services sector and the problems of its management. It is worthwhile to speculate that this harmony of theory and practice is due in part to the dual role, as consultant - or practitioner-at-one-remove - and theoretician, played by a number of leading contributors. (Consider the role of the consultant as agent for theory development as exemplified by the work of the Boston Consulting 


\section{Group and the McKinsey Company.)}

Services marketing is concerned with organising and 'delivering' marketing and customer satisfaction in a very practical way. We referred earlier to the abstract notion of marketing orientation often exemplified by conventional product marketers; there is concern about considerations of strategy and marketing mix resolution, but little about translating this process into actual buyer loyalty 'by getting hands dirty'. Services marketing, on the other hand, embraces these issues of order generation, fulfilment and service delivery. Its concern with mapping and blueprinting delivery systems (Shostack, 1981, Kingman-Brundage, 1995) across the total organisation should be emulated by product marketers.

These process blueprints involve a deep understanding of organisations and of organising people. Yet such concern for issues of organisation theory and structure in services marketing is not as pervasive as might be expected in the literature. A content analysis of a recently published book of text and 'classic' readings, charting the growth of services marketing (Carson and Gilmore, 1996), shows the word organisation, in its sense of an organogram, to occur just three dozen times throughout 19 such articles.

Services marketing's emphasis on its differences from product marketing could easily become hubris. The similarities are equally great. Consumer, business to business and services marketing are profoundly enveloped in one another. Marketing as a discipline needs more systemic and holistic approaches. At the least, the oft touted 3 extra Ps of services marketing, people, processes and physical evidence, (should) belong in product marketing as well. One hopes that Bateson has his tongue firmly in cheek when he writes in the preface to his latest edition: "Every textbook on marketing should be based upon services with a couple of chapters at the end on 'the special case of goods'" (Bateson, 1995, p. vii). Indeed this shortsightedness is further compounded when it is considered that much first rate service delivery takes place in many firms with only a very small involvement of the conventional marketing department. The appellation services management seems more apposite.

\section{Green Marketing}

Green marketing is a subdiscipline at the 'crawling out' stage, to use Fisk et al.'s (1993) terminology. Two broad threads of exploration can be discerned (McDonagh and Prothero, 1997). First, there is the issue of how firms can take advantage of ecological concern to offer new products and services and in general to manage marketing in a manner that confers positional gain. Second, marketing is viewed as a proactive player in the green movement and is urged to resolve possible dilemmas in a societally responsible way.

In the first instance, as ecological consciousness broadens, and green issues become more mainstream, it is likely that such strategic and tactical issues will be subsumed into general marketing theory. In the second, conventional definitions of marketing's remit circumscribe consideration of social responsibility and marketing; such ethical issues tend to be driven into the wider domain of business ethics and ethics itself.

Further, green marketing seems strangely ambivalent, if not confused, about 
the sovereignty of the consumer. In the context of often complex issues about whether certain products and services may damage the environment and human health, the catchcry that the consumer is king, and a fully capable decision maker, is simplistic. Consumers look to firms as well as to governments and specialist agencies to inform them reasonably and reassuringly about products. The response can be flawed. Thus green marketing faces considerable difficulties in becoming 'fully erect' (Fisk et al., 1993), and it is arguable that its status as a subfield may dissolve, much as happened to societal marketing in the 1980s.

\section{Change in Theory: The Functional Disciplines}

The brief examination of developments in the theory of marketing and its subfields indicates shortcoming. This is a lack of synchrony between theory and practice. With the exception of services marketing and dimensions of relationship marketing, theoretical progression in the academy lags behind the changing nature of practice. The broad body of knowledge of which the academy is a custodian and promulgator belongs and seems more relevant to an era of practice that has disappeared in large measure. This begs the question of how developments in other functional disciplines of business are impacting on marketing.

\section{Finance}

One of the more managerially significant developments in the area of finance during the eighties was the development of shareholder value (Rappaport, 1986) and economic value added approaches to assessing companies and their strategies. The interest was sparked by, among other pressures, the huge wave of corporate restructuring through merger and acquisition activity, by the reversal of the diversification trend of the seventies and a return to core business. Kay $(1993,203)$ notes that "by the end of the decade few US companies failed to include a reference to the concept in their annual report". Not just a theoretical development but also a major adjustment in practice at leading companies in North America and Europe, the approach presses for the evaluation of business and corporate strategy in terms of the specific addition to, or dilution of, shareholder value through the analysis of expected cash flows. Shareholder value may be measured as the excess return to shareholders - the amount by which the total return they earn, taking dividends and capital gains together, exceeds the cost of capital. Adoption of the approach demands that all strategies be evaluated in this manner, including those of marketing. There is nothing particularly shocking about such demands on strategy evaluation except when one inspects the record of strategy and investment appraisal in the practice of marketing and in the related normative literature, one finds little if any consideration of the approach. One of the few voices was Day's (1990) work on market led strategies. Does both marketing practice and theory avoid the harsh measurement realities and the necessity to justify decisions in even moderately rigorous financial terms? The answer seems to be yes!

\section{Manufacturing/Operations}

Among the so-called functional disciplines of management, manufacturing or 
operations management, along with human resource management, has experienced the greatest revolution. From a vary mature base of knowledge, based principally on concepts, methods and techniques aimed at optimising traditional manufacturing systems, it became the intellectual battleground on which the international competitive battle between Japanese and Western industry was waged. In tandem with this struggle it stretched its scope to deal with the design and optimisation of operations in the service industries. In the process it stepped outside its traditional focus on improving efficiency within given operations frameworks and confronted the task of reconceptualising those frameworks. In doing so it provided the conceptual apparatus that finally introduced the quality movement on a wide scale to Western industry and adopted a central focus on customer responsiveness.

The quality movement was central to the revolution in operations management. Total quality management (TQM) concepts demand the direct involvement of all employees in decision making. This requires the decentralisation of authority and responsibility and a focus on continuous improvement which demands that teams be drawn together around fundamental manufacturing and service processes. The commitment to customer responsiveness stretched the operations management framework outward from the factory through the distribution system to the final customer and 'backward' to the sources of raw material. Suddenly operations management theory was dealing with supply chain management from raw material to end use and in the process undertaking much of the work that an effective marketing discipline should have pioneered years earlier. In developing its new concepts of world class manufacturing, lean production and process reengineering (e.g., Hayes and Wheelwright, 1984; Davenport and Short,1990; Hammer and Champey, 1993), manufacturing's traditional engineering and quantitative methods strengths brought discipline, detailed measurement and optimisation techniques to bear on the subtle processes involved in delivering quality products and services to customers. McKitterick's (1957) seminal paper on the 'marketing concept' and Levitt's (1960) provocation about 'marketing myopia' might never have been written or endlessly quoted for all the impact they ultimately had within marketing. It was colleagues in operations management who had never encountered their writings who just got on with the job of recreating competitiveness in the face of the Japanese onslaught by designing for customer responsiveness as a prime requirement of any production system.

Through its work on new product development, and especially its conceptualisation of simultaneous engineering and team based design and development, manufacturing took the intellectual lead in the area from marketing and forged a theory of integrated, quality assured and time critical development that had evaded marketing's efforts in the area. Finally, with the development of new production techniques in the area of flexible manufacturing and mass customisation it has presented marketing with one of its holy grails the possibility of dealing pragmatically with segments of one. These are opportunities yet to be fully exploited by marketing theory, although marketing practitioners such as those at Levi's and National Panasonic Bicycle are well on 
the way to implementation in areas as diverse as clothing and bicycles (Levi Strauss \& Co., 1997; Westbrook and Williamson, 1993).

\section{Human Resource Management}

Human resource management has had its revolution too - dramatically signalled by sloughing off its old skin - its label of personnel management - and emerging with a new name to match its reformed identity and conceptual orientation. At the heart of the transformation lies the orientation well captured by the title of one of the more popular textbooks Organisation Capability: Competing from Inside Out (Ulrich and Lake, 1990).

As with operations management, redirection of focus away from an internal and efficiency orientation to an external, effectiveness and competitiveness of the firm orientation has marked the central change in the discipline. Typically, HRM theorists and practitioners will now first ask what are the goals and strategies of the organisation and then address the question of how best to design and develop the human resource management system to support those strategies and achieve the goals. Understanding people and associated systems and structures as instruments of organisational purpose is therefore a central platform. Other than in services marketing, the HRM-marketing interface is poorly developed in general as the theme of people and organisation has not been well developed in marketing thought. It is one that should be much more easily developed in so far as both disciplines can see their purpose as coterminus in the competitive success of the firm.

\section{Strategy}

The field of strategy has grown dramatically in importance in the past two decades. It has moved beyond its association with planning (Mintzberg, 1994) to an emphasis on the process and content issues in decision making which affect the direction and competitive success of the organisation. It has also developed a strong pormalised analytical and research driven basis in contrast to the older business policy tradition. It has explored several contrasting approaches to the explanation of strategic success. The initial growth of strategic management was fuelled by an external, adaptive or 'strategic fit' approach to explanation, culminating in Porter's development of the industrial economics view of industry structure determining firm behaviour and that in turn determining firm level performance (Porter, 1980).

This orientation sat easily with marketing and saw a considerable and productive conversation at its interface with strategy in and around the topic of strategic market planning (Abell and Hammond, 1979) and strategic market management (Aaker, 1984). It sat particularly comfortably because of the congruence between the external (industry, markets and competition) orientation and the 'marketing concept' philosophy. Both stress adaptive behaviour by indicating that one proceeds analytically by figuring out the industry/market/consumer and then by gearing strategic marketing to serve the demands/needs so identified. Both had a similar missionary zeal about turning managerial eyes outward and about starting decision making in external facts and only then reverting to internal matters. But both have had to bear the 
burden of difficulties arising from an adaptive approach - especially where adaptive is likely to become reactive. In both instances, they have faced harsh criticism for providing a conceptual framework that could be seen to justify conservatism ('fit' vs. 'stretch') and to avoid creativity and entrepreneurialism (Hamel \& Prahalad, 1991).

In more recent times, strategic management has explored a wider and richer field of theoretical insight in its drive for explanation and prediction of corporate success. The so-called resource based view (e.g. Barney, 1986; Grant, 1991; Peteraf, 1993) in particular has developed ideas of competitive advantage around the notion of the firm as a bundle of resources. In this view, competitive advantage comes from the differences in the resource bundles of competing firms and the sustainability of the critical diflerences. For marketing this has presented something of a dilemma: if you must compete from the resource base, where does the market and customer fit in? The answer is of course in conceptualising marketing as part of the resource bundle. But this draws attention to marketing competencies, their definition and management and especially to the intellectual capital of marketing and to the organisational arrangements most likely to make that capital productive. These are considerations to which marketing has not devoted much attention in recent times but must now do so if it is to maintain its dialogue with strategy. For example, the recent work of Falkenberg $(1996,4)$ divides a firm's resources into physical assets, valuable paper (e.g. cash), and "behavioural assets" which are defined as the "routines and competencies of the people involved ... which are located not only inside, but outside the firm". Falkenberg contends that such behavioural assets are the principal source of wealth creation for the firm.

\section{Change in Theory: Cognate Disciplines}

Marketing has always been a borrowing discipline, particularly from economics and from the behavioural sciences. Borrowing continues and in some areas is needed if markets and marketing are to be adequately explained and managed. It is impossible to summarise all the actual and potential interchange with cognate disciplines so this can only be a subjective and partial coverage, reflecting above all the borrowing inclinations of the two authors.

\section{Economics}

While classical and neo-classical microeconomics has been the traditional borrowing ground, recent years have seen a revival of interest in some important and long standing ideas about the theory of the firm (Coase, 1937). Williamson's (1985) work on transaction costs and on markets and hierarchies as alternative ways of governing transactions may be deployed to provide explanations of market structures within industries and of firms within industries (Murray and O'Driscoll, 1996b and 1997). This line of explanation draws attention to the manner in which whole industries are structured and restructured and to the issues of vertical and horizontal integration, while also shedding light on the forces at work in the processes of industry revolution and organisational outsourcing - central features of the past decade of change in the industrial world. This might be seen as being of principal interest to the strategy 
field, but it is also central to marketing theory since it provides explanations for the nature and structure of markets and managerial implications concerning choice of governance structures. It also provides a much needed theoretical context for those researching and managing 'internal marketing' processes - i.e. transactions governed by hierarchy/internal organisation rather than by arm's length contract.

The interpenetration of economics and strategy is high in the underpinnings of the resource based school. It passes a challenge on to marketing in the clear necessity to conceptualise marketing competence (capability to be precise) and marketing organisation and the manner of its deployment as a core competitive asset. Furthermore, it demands theory that would explain the sustainability of this marketing asset and how it might be defended by managerial action to create barriers to imitation: imitability, tradeability and mobility (Peteraf, 1993). Marketing needs to understand itself and its organisational configuration much more than has been characteristic of its managerial and academic past and there are theoretical constructs waiting to be exploited in adjacent disciplines.

\section{Decision Making}

Despite marketing's unique focus on buyer and consumer behaviour it has always used a central assumption of analytical rationality (based on assumptions of clear and non-conflicting objectives, analysis of full information and decision making according to a decision payoff optimising calculus based on defined criteria) when addressing managerial and consumer decision making and in its explanations of market phenomena. This has been partly acknowledged in the more recent critique of consumer behaviour and its models and their weakness in explaining observed behaviour. It is reflected in the search for models to explain low involvement purchase decisions and those visibly unexplained by the rational-analytic paradigm.

Marketing has not been alone among management disciplines in failing to come to terms with the reality of observed decision making. It is only recently that Whittington (1993) in his charming book What is Strategy and Does it Really Matter? has popularised long standing alternative models of decision making in the field of strategy, although he follows in the steps of Quinn's work on logical incrementalism and Mintzberg's well established distinction between intended and emergent strategy (Mintzberg, 1994). It is striking to note just how long alternative models have been established in the field of policy studies and policy analysis. Lindblom, a political scientist, wrote his striking paper on disjointed incrementalism - 'muddling through' - in 1959 and there were already well established non-rational analytical models based on the work of Simon (1947), March and Simon (1958), Allison (1971) and the cybernetic concepts of Ashby (1952) and Steinbruner (1974). Despite this depth of theory, research in marketing, and its normative pressures on the practice of marketing, are overwhelmingly rational-analytical. This is a puzzle, since empirical reality points so clearly to the need for explanations other than the rational-analytical. It seems that that there is a significant disconnection between the normative and the positive aspects of the discipline: what it says should be done and what it observes is done. This might be explained by noting how little attention the 
discipline pays to how decisions are made and implemented by marketing practitioners as well as customers; by what appears to be a profound lack of interest in the workings of marketing management - at best an interest in marketing but not in management? Once again, there must be much to be gained from long and well established theory in related disciplines.

\section{Organisation Theory}

The modern market and industry landscape is increasingly characterised by new forms of industrial organisation. Principal among these new forms is that of the network organisation. Miles, Snow and Coleman (1992) have drawn attention to the emergence of the network organisation in their important revision to their seminal work (Miles and Snow, 1978) on organisational configuration. All organisations are networks. Indeed, firms might be considered as networks of markets which are formally organised. Markets whether formally organised within firms, or connected by transactions governed by contract or social obligation - typically cluster in sets of interconnected relationships which purposefully produce products and/or services. Network organisations are neither hierarchically organised within firms nor singularly coordinated to produce one unique output. They produce repeated outputs in a predictable but highly flexible manner, which achieves integration that is horizontal, vertical and spatial, and which integrates across multiple formal boundaries. With their dominant characteristics of flexibility and selfadaptation, they seem especially suited to customised projects, close customer and supplier involvement in the production and logistics process and to complex turbulent environments (Baker, 1992). Think about a U2 world tour, General Electric's concept of a 'boundary-less' organisation or Benetton's evolution in the Pashion outerwear industry and you have the applied counterpart.

It is noteworthy that a number of marketing scholars, largely drawing on a resource based view of the firm, endorse such thinking about networks and organisational structures. Gummesson $(1995,17)$ refers to "structural capital", which he defines as "those resources built into the organisation such as systems, procedures, contracts, and brands which are not dependent on single individuals". There is increasing emphasis on recognizing that the total value of a firm is primarily determined by what Gummesson calls soft assets, not inventory and equipment. Thus, the intrinsic worth of many organisations cannot be correctly assessed from traditional profit and loss and balance sheet statements. Srivastava et al. $(1998,2)$ argue similarly in their framework for developing and managing "market based assets, or assets that arise from the comingling of the firm with entities in its external environment". Such relational and intellectual assets include customer relationships, channel expertise, brand equity, special knowledge of market conditions and so on.

This emergent reflection on organisational form and interrelationships dramatises the extent to which the organisation of markets is fundamental to organisation theory, as it has been fundamental before to the economic theory of the firm. But it has been a virtually non-existent concern for marketing theory until recently when relationship marketing and business to business marketing 
started to take interest in the governance of markets. Marketing has lost touch with markets. We have already asked whether it may also have lost interest in management. If both questions are answered in the afîrmative, with what are we left? The answer is marketing. But it is marketing as interpreted by what Sheth, Gardner and Garrett (1988) define as the managerial school of marketing. They note that "the strength and popularity of the management school can be traced to its uncomplicated, elegant focus on such concepts as the marketing concept, marketing mix, product life cycle, and market segmentation" concepts popularised by pioneers such as Dean, Howard, Smith, Borden, Lazer, Levitt and Kotler. But the growth and subsequent dominance of the managerial school with its emphasis on American consumer marketing practice of the fifties and sixties has been at the expense of a parallel loss of interest in marketing theory (Sheth, Gardner and Garrett, 1988, 25). We believe that this has now become a threatening liability, since the practice which informed its principles, generalisations and techniques has all but disappeared as the predominant form of managerial practice. There is need to engage with the practice of the day. Srivastava et al. $(1998,2)$ more optimistically contend "old inviolable assumptions about the purpose, content, and execution of marketing slowly are giving way to assumptions that more accurately reflect how it is practised in leading organisations".

\section{Synchrony in Theory and Practice}

\section{Theory and Research}

It is argued that developments in the theory of marketing and its subfields indicate shortcoming. There is a lack of symmetry between theory and practice. To explain this disharmony, we are of the view that one important consideration lies in the basic thrust of much research in marketing undertaken by the academy over past decades. The focus of research effort has tended towards theory (dis)confirmation and validation rather than theory creation and building, with an accompanying emphasis on the use of quantitative, survey techniques of enquiry. But theory generation, particularly in the social sciences, also involves 'softer', often exploratory, qualitative approaches. Case studies, single site longitudinal studies, ethnographic and phenomenological techniques all have a role in creating new understanding and views about how the world of marketing works. Despite exhortation to embrace such approaches (Bonoma, 1985; Gummesson, 1991), the academy has been slow to do so.

It is worthwhile to observe that the two domains we identify of harmonious development in theory and practice - relationship marketing, with its antecedents in the IMP group and Nordic network approach, and services marketing - are domains where theory building and a balance of qualitative as well as quantitative approaches patently underpin research. In a discipline like marketing with its closely associated area of professional endeavour, scientific enquiry is a journey not an endpoint. The ultimate validity of a theory is its usefulness in practice. As practice evolves and some concepts become redundant, there is need not only to refine and re-test existing theory but to generate fresh thinking. Qualitative research has a key role. There are signs of 
change, of a shift in balance towards theory building and perforce qualitative approaches. It is possible to detect an increasing use of such methodology in the research being published in current marketing periodicals (Gilmore and Carson, 1996). Such research approaches also involve the academy in restructuring itself to accommodate new assessment and rewards structure for its members and new resource allocation decisions; qualitative methodologies often necessitate longer time horizons and greater expense than conventional quantitative techniques.

Others argue in more radical fashion that marketing as a discipline has been fixated futilely with science and scientific method. Brown $(1996,260)$ concludes that much of post-war marketing scholarship is wanting and a waste of time, "an heroic but utterly wrongheaded attempt to acquire the unnecessary trappings of "science". He maintains that "marketing's ill-advised quest for scientific respectability has only served to alienate its principal constituents practising managers and prospective managers". Art and a sense of the aesthetic may have an important role in understanding marketing. Brands, for example, are a cornerstone of marketing effort and much scientific examination is invested in explaining their success. But it is an approximate business and while such research may become more exact with time, one might also acknowledge the manager's contention that 'brands are beautiful'.

\section{Learning and Synchrony}

In this limited scan of the state of both theory and practice in marketing and of the interfaces both within and between the two, we have proceeded on the assumption that synchrony is of value. This assumption seems warranted on the grounds that the existence of synchrony is likely to lead to efficiency in action and in learning. Where the fields of practice and theory are advancing with internal congruence; where different aspects of practice and theory are mutually supportive and provide each other with positive stimulation and spillover learning; and where the domains of theory and practice are externally congruent with each other in the same way, the liklihood of efficiencies in each others' work; of economies of scale through cumulative and convergent learning; and of economies of scope in learning must be significant. By contrast where asynchrony is the dominant theme, the potential for fragmentation, contradiction, confusion and disengagement of theory from practice must be proportionately large. If the state of theory and practice is viewed as representing the stock of knowledge about marketing - its intellectual capital the taxonomy proposed by Stewart (1997) may be used to tease out the issue of synchrony a little further. Stewart distinguishes between human, structural and relationship capital as elements of intellectual capital. The human element is that part stored in individual brains and used individually. But he makes the point that "smart individuals don't necessarily make for smart companies" (Stewart, 1997, 76) much as one might add that smart academicians and practitioners are not sufficient to make a smart discipline. Sharing and 'leveraging' knowledge requires what he calls structural intellectual assets that "turn individual know-how into the property of a group"(ibid). Customer, or relationship capital if one looks up and down the supply chain, is the "value of 
an organisation's relationships with the people with whom it does business" (ibid, 77) and he notes that it is in these relationships that intellectual capital turns into money.

If the invisible college of marketing academicians and practitioners is viewed as a virtual organisation dedicated to the creation, development and application of a specialised form of intellectual capital it might be suggested that while there is plentiful human capital involved in the enterprise, the structural capital is deficient - the sharing and leveraging of knowledge is hindered by inadequate synchrony between researcher, teacher and practitioner. Marketing's intellectual problem may be one more of community than anything else. On a parallel theme, de Gues (1997) notes that accelerated evolution in biology appears to depend on innovation, social propagation and mobility. Innovation is the ability to develop new skills to exploit new environmental conditions. Social propagation involves the direct communication within a community of the new skills, while mobility involves the freedom and practice of congregating and moving. The moving flock seems to beat the isolated territorialist. The sense of asynchrony which prompted this paper has much to do with a sense of failure in social propagation and 'flocking'.

Our sense of the field is that there is considerable doubt in the practice of marketing but very active experimentation and learning as the practitioner community seeks to come to terms with new market, technological and organisational realities. The field of practice has had its moment of panic in the early 1990s (Brady and Davis, 1993; Coopers and Lybrand, 1993; The Economist, 1994) as many leading firms that had set the norms of good practice re-organised in ways that laid the future of marketing in its functional/departmental embodiment open to the most serious doubt. The panic would not appear to have to led to collapse but rather to re-invention. It is our sense that marketing practice is re-creating its principles and organisational form. In this context we perceive a practitioner community with an immediate and insistent demand for new and better theory, frameworks, and models to guide, explain, predict and support management action. The current generation of practitioners grew up and was educated in the managerial school, whose foundations they are presently re-creating. To them, the lack of synchrony is all too evident.

Our sense of the state of the academy is less phlegmatic. We worry that the interface with practice is increasingly asynchronous: above all we worry that the academy has not yet had its moment of panic; has not yet had its galvanising moment; has not yet acknowledged the possibility that its centre of gravity - especially in teaching and in research to some lesser extent - is firmly related to a practice that has been abandoned at the leading edge and is being abandoned steadily by the followership of the profession.

\section{Building New Theory}

But our concern is not just with the immediate asynchrony between the fields of theory and practice. It is also with the impoverishment of thinking within the theory domain. We have suggested that marketing is uninterested in markets, managing, and organisation; that its scope has been limited by over- 
convergent thinking on marketing as managerial practice, as constructed by the great consumer goods companies of the fifties, sixties and seventies. To restore a convergence with practice we suggest that theory needs not just to deal with the new realities of marketing but also to develop its theories of markets, managing and organising. It must develop better understanding of markets, their structures, dynamics and governance because they are the context for all else that is of interest to the discipline. It must develop a better understanding of organising because the organisation of marketing is changing out of all recognition and it is in its organisation that the firm creates resource based market advantage. It must develop a better understanding of managing because it is through managing and decision making that the marketing 'resource bundle' is turned into competitive advantage in ways that yield strategic market asymmetries - in other words, in ways that create defensible market advantage for the firm.

Our argument for the benefits of synchrony should not be taken in too extreme a fashion. We readily concede that complete harmony is likely to produce, through the absence of intellectual and applied conflict, a smug conservatism that leads quickly to sclerosis. We might even be tempted to argue that such a premature synchrony originating in the late sixties was the origin of many of the ills for which we now criticise the discipline. Some degree of asynchrony, just like healthy conflict in any social system, is a necessary ingredient for intellectual progress and for a productive discourse between practitioner, teacher, learner and theorist. We believe that the good news is that the current asynchronous state of the discipline is the necessary (but insufficient!) breeding ground for frame breaking theory, for paradigm shift. We suggest that the bad news is that if we in the academy are unsuccessful in our response, or just simply uninterested in responding, then this is the burial ground for irrelevant theory.

\section{References}

Aaker, D.A. (1984), Strategic Market Management, 1st ed., Wiley, NY.

Abell, D.F. and J.S. Hammond (1979), Strategic Market Planning, Prentice Hall, NJ.

Allison, G.T. (1971), Essence of Decision: Explaining the Cuban Missile Crisis, HarperCollins, NY.

Anderson, R.E. (1996), "Personal selling and sales management in the new millennium", Journal of Personal Selling \& Sales Management, vol. 16, no. 4, pp. 17-32.

Ashby, W.R. (1952), An Introduction to Cybernetics, Chapman \& Hall, London.

Baker, W.E. (1992) "The network organisation in theory and practice", in N. Nohria and R.G. Eccles, eds., Networks and Organisations, Harvard Business School Press, Cambridge, MA, pp. 297-329.

Barney, J.B. (1986), "Strategic factor markets: expectations, luck and business strategy", Management Science, vol. 32, pp. 1231-1241.

Bartlett, C.A. and S. Ghoshal (1989), Managing Across Borders: The Transnational Solution, Hutchinson Business Books, London, pp. 57-71. 
Bateson, J.E.G. (1995), Managing Services Marketing: Text and Readings, The Dryden Press, Fort Worth, TX.

Belk, R.W., N. Dholakia and A. Venkatesh, eds. (1996), Consumption and Marketing: Macro Dimensions, International Thomson Publishing, Cincinnati, $\mathrm{OH}$.

Boehm, R. and C. Phipps (1996), "Flatness Forays", The McKinsey Quarterly, no. 3 , pp. $32-48$

Bonoma, T.V. (1985), The Marketing Edge, Free Press, NY.

Brady, J. and I. Davis (1993), "Marketing's mid-life crisis", The McKinsey Quarterly, no. 2, pp. 17-28.

Brown, S (1997), Postmodern Marketing Two, ITP, London.

Brown, S. and D. Turley, eds. (1997), Postcards from the Edge: Leading Issues in Consumer Behaviour, Routledge, London.

Brown, S. (1996), "Art or science?: fifty years of marketing debate", Journal of Marketing Management, vol. 12, pp. 243-267.

Brown, S (1995), Postmodern Marketing, Routledge, London.

Business Week (1994), "Database marketing: a potent new tool for selling", 5 September.

Carson, D. and A. Gilmore (1996), Services Marketing: Text and Readings, Mercury Publications, Dublin.

Coase, R. (1937), “The nature of the firm", Economica, vol. 4, pp. 386-405.

Coopers and Lybrand (1993), Marketing at the Crossroads, Coopers and Lybrand, London.

Davenport, T.H. and J.E. Short (1990) ,"The new industrial engineering: information technology and business process redesign", Sloan Management Review, summer, pp. 11-27.

Day, G.S. (1990), Market Driven Strategy: Processes for Creating Value, Free Press, NY, pp. 333-355.

de Gues, A. (1997), The Living Company, Harvard Business School Press, Cambridge, MA, p. 133.

Easton, G. and H. H\%okansson (1996), "Markets as networks: editorial introduction", International Journal of Research in Marketing, vol. 13, no. 5, pp. 407-413.

The Economist (1994), "Death of the brand manager", 9 April, pp. 71-72.

Falkenberg, A. (1996), "Marketing and the wealth of firms", Journal of Macromarketing, vol. 16, spring, pp. 4-24.

Fanning, J. (1997), "Is the end of advertising really all that nigh?", Irish Marketing Review, vol. 10, no. 1.

Fisk, R.P., S.W. Brown and M.J. Bitner (1993), "Tracking the evolution of the services marketing literature", Journal of Retailing, vol. 69, spring, pp. 61-103.

Ford, D., ed. (1990), Understanding Business Markets: Interaction, Relationships, Networks, Academic Press, London.

George, M., A. Freeling and D. Court (1994), "Reinventing the marketing organisation", The McKinsey Quarterly, no. 4, pp. 43-62.

Gilmore, A. and D. Carson (1996), "Integrative' qualitative methods in a services context", Marketing Intelligence and Planning, vol. 14, no. 6, pp. 21-26.

Grant, R.M. (1991) "The resource based theory of competitive advantage: 
implications for strategy formulation", California Management Review, vol. 33, no. 3, pp. 114-135.

Gummesson, E. (1996a), "Relationship marketing and imaginary organizations: a synthesis", European Journal of Marketing, vol. 30, no. 2, pp. 31-44.

Gummesson, E. (1996b), "Mega and nano relationships in relationship marketing", Irish Marketing Review, vol. 9, pp. 9-16.

Gummesson, E. (1995), "Focus shifts in marketing: a new agenda for the third millennium", presentation at the 20th anniversary programme of the Marketing Technology Centre (MTC), Stockholm.

Gummesson, E. (1991), Qualitative Methods in Management Research, Sage Publications, Inc., Newbury Park, CA.

Häkansson, H. and J. Johanson (1992), "A model of industrial networks", in B. Axelsson and G. Easton, eds., Industrial Networks: A New View of Reality, Routledge, London.

Hammer, M. and J. Champey (1993) Reengineering the Corporation, Brearley, London.

Hamel, G. and C.K. Prahalad (1991), "Corporate imagination and expeditionary marketing", Harvard Business Review, July-August, pp. 81-92.

Hayes, R.H. and S.C. Wheelwright (1984), Restoring Our Competitive Edge, Wiley, NY.

Howard, J. and J.N. Sheth (1969), The Theory of Buyer Behaviour, Wiley, NY.

IMP Group (1982), An Interaction Approach, Wiley, Chicester.

Kay, J. (1993), Foundations of Corporate Success, Oxford University Press, NY.

Kingman-Brundage, Jane (1995), "Service mapping: back to basics" in W.J. Glynn and J. G. Barnes, eds., Understanding Services Management, Oak Tree Press, Dublin, pp. 119-42.

Kuhn, T.S. (1970), The Structure of Scientific Revolutions, University of Chicago Press, Chicago, IL.

Langeard, E., J. Bateson, C. Lovelock and P. Eiglier (1981), Marketing of Services: New Insights from Consumers and Managers, report no. 81-104, Marketing Science Institute, Cambridge, MA.

Levi Strauss \& Co. (1997), Levi's Personal Pair ${ }^{\circledR}$, Levi Strauss \& Co., London.

Levitt, T. (1960), "Marketing myopia”, Harvard Business Review, July-August, pp. 24-47.

Lindblom, C.E. (1959), "The science of 'muddling through", Public Administration Review, vol. 19, pp. 78-88.

March, J. and H. Simon (1958), Organisations, Wiley, NY.

McDonagh, P. and A. Prothero (1997), "Green marketing: an introduction", in P. McDonagh and A. Prothero, eds., Green Management: A Reader, The Dryden Press, London, Part V.

McKitterick, J.B. (1957), "What is the marketing management concept?", in F.M. Bass, ed., The Frontiers of Marketing Thought, American Marketing Association, Chicago, IL, pp. 71-82.

Meenaghan, T. (1995), "Marketing communications in transition", in T. Meenaghan and P. O'Sullivan, eds., Marketing Communications in Ireland, Oaktree Press, Dublin.

Micklethwaite, J. and A. Wooldridge (1996), The Witch Doctors: What the 
Management Gurus are Saying, Why it Matters and How to Make Sense of it, Heinemann, London.

Miles, R., C. Snow and G. Coleman (1992), "Managing 21st century network organisations", Organisational Dynamics, winter, pp. 188-98.

Miles, R and C. Snow (1978), Organizational Strategy, Structure and Process, McGraw-Hill, NY.

Mintzberg, H. (1994), The Rise and Fall of Strategic Planning, Prentice Hall, Hemel Hempstead.

Muranyi, N.R. (1997), "Database marketing in FMCGs: what is the state of the art?", Journal of Database Marketing, vol. 4, no. l.

Murray, J.A. and A. O'Driscoll (1997), "Messianic eschatology: some redemptive reflection on marketing and the benefits of a process approach", European Journal of Marketing, vol. 31, no. 9/10, pp. 706- 719.

Murray, J.A. and A. O'Driscoll (1996a), "Reconsidering the management of marketing", Irish Marketing Review, vol. 9, pp. 35-47.

Murray, J.A. and A. O'Driscoll (1996b), Strategy and Process in Marketing, Prentice Hall, Hemel Hempstead.

Murray, J.A. (1994), "Marketing is dead", The Marketing Communicator, vol. 10, pp. 5-9.

Nicosia, F.M. (1966), Consumer Decision Processes, Prentice Hall, NY.

Nowak, G.J. and J. Phelps (1994), "Conceptualisizing the integrated marketing communications' phenomenon: an examination of its impact on advertising practices and its implications for advertising research", Journal of Current Issues and Research in Advertising, vol. 16, no. 1, pp. 49-66.

O'Driscoll, A. (1997), "Marketing from the periphery", in A. O'Driscoll, ed., Marketing in Action: Learning from a Small Country, Mercury Publications, Dublin, p. 3.

Ostroff, F. and D. Smith (1992), "The horizontal organisation”, The McKinsey Quarterly, vol. 1.

Parasuraman, A., V. Zeithaml, and L. Berry (1988), "SERVQUAL: a multiple-item scale for measuring customer perceptions of service quality", Journal of Retailing, spring, pp. 12-40.

Peterai, M. (1993), "The cornerstones of competitive advantage: a resource based view", Strategic Management Journal, vol. 14, no. 3, pp. 179-192.

Porter, M. (1980), Competitive Strategy: Techniques for Analyzing Industries and Competitiors, The Free Press, NY.

Rappaport, A. (1986), Creating Shareholder Value: The New Standard for Business Performance, The Free Press, NY.

Reichheld, F.F. and W.E. Sasser (1990), "Zero defections: quality comes to services", Harvard Business Review, Sept-0ct, pp. 105-111.

Senge, P.M. (1990), The Fifth Discipline: The Art and Practice of the Learning Organisation, Century Business, London.

Sheth, J.N. (1973), "A model of industrial buyer behaviour", Journal of Marketing, vol. 37, no. 4.

Sheth, J.N., D.M. Gardner and D.E. Garrett (1988), Marketing Theory: Evolution and Evaluation, Wiley, NY.

Shostack, G.L. (1981), "How to design a service", in J.H. Donnelly and W.R. 
George, eds., Marketing of Services, American Marketing Association, Chicago, pp. 221-229.

Simon, H.A. (1947), Administrative Behaviour, Macmillan, NY.

Sparks, L. (1995), "Slaying the giants? The Cott Corporation and retailer brand soft drinks in Great Britain and the USA", Annual Conference Proceedings of the Marketing Educators Group (MEG), Bradiord, p. 973.

Srivastava, R.K., T.A. Shervani and L. Fahey (1998), "Market-based assets and shareholder value: a framework for analysis”, Journal of Marketing, vol. 62, January, pp. 2-18.

Steinbruner, J. (1974), The Cybernetic Theory of Decision, Princeton University Press, Princeton, NJ.

Stewart, T.A. (1997), Intellectual Capital: The New Wealth of Organisations, Doubleday, NY.

Ulrich D. and D. Lake (1990), Organisation Capability: Competing from Inside Out, Wiley, NY.

Webster, F. and Y. Wind (1972), Organisational Buyer Behaviour, Prentice Hall, NY.

Westbrook, R. and P. Williamson (1993), "Mass customisation: Japan's new Prontier", European Management Journal, vol. 11, no. 1, pp. 38-45.

Whittington, R. (1993), What is Strategy and Does it Really Matter?, Routledge, London.

Williamson, O.E. (1985), The Economic Institutions of Capitalism ${ }_{1}$ The Free Press, New York. 
() of Journal of Marketing Management is the property of Westburn Publishers Ltd or its licensors and its content may not be copied or e-mailed to multiple sites or posted to a listserv without first obtaining the copyright holder's express written permission. However, users may print, download, or e-mail articles for individual, non-commercial use only. This article has been reproduced by EBSCO under license from Westburn Publishers Ltd. 